\title{
An interactive atlas for marine biodiversity conservation in the Coral Triangle
}

\author{
Irawan Asaad $^{1,2}$, Carolyn J. Lundquist ${ }^{1,3}$, Mark V. Erdmann ${ }^{4}$, and Mark J. Costello ${ }^{1}$ \\ ${ }^{1}$ Institute of Marine Science, University of Auckland, Auckland, New Zealand \\ ${ }^{2}$ Ministry of Environment and Forestry, Jakarta, Indonesia \\ ${ }^{3}$ National Institute of Water \& Atmospheric Research, Hamilton, New Zealand \\ ${ }^{4}$ Conservation International-Asia Pacific Marine Programs, Auckland, New Zealand \\ Correspondence: Irawan Asaad (i.asaad@auckland.ac.nz)
}

Received: 9 July 2018 - Discussion started: 10 August 2018

Revised: 16 December 2018 - Accepted: 18 December 2018 - Published: 30 January 2019

\begin{abstract}
An online atlas of the Coral Triangle region of the Indo-Pacific biogeographic realm was developed. This online atlas consists of the three interlinked parts: (1) Biodiversity Features; (2) Areas of Importance for Biodiversity Conservation; (3) recommended priorities for Marine Protected Area (MPA) Network Expansion (http://www.marine.auckland.ac.nz/CTMAPS). The first map, Biodiversity Features, provides comprehensive data on the region's marine protected areas and biodiversity features, threats, and environmental characteristics. The second provides spatial information on areas of high biodiversity conservation values, while the third map shows priority areas for expanding the current Coral Triangle MPA network. This atlas provides the most comprehensive biodiversity datasets that have been assembled for the region. The datasets were retrieved and generated systematically from various open-access sources. To engage a wider audience and to raise participation in biodiversity conservation, the maps were designed as an interactive and online atlas. This atlas presents representative information to promote a better understanding of the key marine and coastal biodiversity characteristics of the region and enables the application of marine biodiversity informatics to support marine ecosystem-based management in the Coral Triangle region.
\end{abstract}

\section{Introduction}

The advancement of internet technology has led to the development of marine biodiversity informatics, namely information technologies that are employed to support the management of data and information on marine biodiversity (Bisby, 2000; Heidorn, 2011; Parr and Thessen, 2018). They enable people to freely access primary and secondary data over online systems, promote integration of data across datasets, and facilitate collaboration between parties (Costello and Vanden Berghe, 2006). Publicly available biodiversity information is important for engaging the public and policymakers in the addressing of global issues that threaten ecosystem services and functions such as biodiversity loss, climate change, habitat destruction, and overfishing (Costello, 2009). Integration of data across disciplines is increasingly imperative, as biodiversity research requires interactions with other re- lated fields (e.g., genomics, oceanography, climatology, evolution) to foster better analyses and interpretations (Reichman et al., 2011; Costello et al., 2013).

There has been massive improvement in online biodiversity databases covering species names (e.g., WoRMS; Horton et al., 2016), species occurrence records (e.g., GBIF; GBIF, 2018), OBIS; OBIS, 2015), species ranges (e.g., Map of Life: Jetz et al., 2012, AquaMaps; Kaschner et al., 2016), species protection status (e.g., IUCN Redlist; UNEP-WCMC, 2015), biodiversity and fisheries-related data (e.g., Sea Around Us; Pauly and Zeller, 2015), and taxa specific information (e.g., FishBase; Froese and Pauly, 2016, AlgaeBase; Guiry and Guiry, 2018, and sea turtles; Kot et al., 2015) that are managed, curated, and supported by international projects and initiatives. However, the culture of data publishing is still a concern (Costello et al., 2013). Less than $1 \%$ of ecological 
data is accessible after publication (Reichman et al., 2011) and more than $57 \%$ of the papers in environmental biology publications examined in a 2011 review had not released their data (Alsheikh-Ali et al., 2011).

Biodiversity informatics is expected to grow exponentially. Software, infrastructure, and management tools to store, publish, and share biodiversity data, particularly over the internet and World Wide Web, have been improved significantly in recent years (Michener, 2015). Such development is supported by the availability of metadata standards to facilitate description of datasets and data records (e.g., Ecological metadata language (EML); Michener et al., 1997); Darwin core; GBIF, 2010), widely assessed repositories for depositing ecologically relevant data (e.g., Dryad; http://datadryad.org/; Figshare; https://figshare.com/; KNB; https://knb.ecoinformatics.org/) and a variety of open-source data management tools (e.g., MySQL, R, and Kepler).

Geographic information systems (GIS) provide a tool to explore spatial relationships within and between data (Wright et al., 2016; Hamylton, 2017), and there is a growing trend of internet-based GIS (i.e., GIS designed for operating online over the World Wide Web) (Morets, 2017). The application of internet GIS through online atlases (the process of designing, generating, and delivering maps on the internet) provides a number of advantages over traditional desktopbased GIS (Neumann, 2008). Web-based maps can deliver up to date data, can be generated using a low-cost software and hardware infrastructure, and facilitate inexpensive map distributions. In addition, online atlases enables the integration of different data sources and collaborative mapping (e.g., Google Maps, Openstreet Maps; Neumann, 2008; Fu and Sun, 2010; Clarke, 2014). These geo-based websites applications are supported by Open GIS infrastructure that allow users in the world to access and operate GIS and to facilitate the exchange of spatial data and information (Sui, 2014). In the biodiversity conservation discipline, online atlases offer greater accessibility and allow for user-driven interaction (Peterson, 2018). Furthermore, the advancement of smartphone applications (apps) that are linked to mobile webbased maps provides an avenue to involve broader audiences in the natural sciences and a convenient tool for scientists to disseminate their research (Teacher et al., 2013; Marchante et al., 2017). Online atlases exist for several coastal regions, including Ireland's Marine Atlas (https://atlas.marine.ie/), the Oregon Coastal Atlas (https://www.coastalatlas.net/), and the European Atlas of the Seas (Barale et al., 2015). These coastal web-atlases serve a variety of functions, including being data repositories, and allow users to explore and overlay different data with geospatial analysis tools. Therefore, Wright et al. (2011) define the coastal online atlas as "a collection of maps with supplementary tables, illustrations, and information which systematically illustrate the coast".

To take advantage of the potential of online atlases, here we developed an application for the Coral Triangle (CT) region of the Indo-Pacific realm, a marine area situated be- tween the Indian Ocean and Pacific Ocean and a global focus for marine biodiversity conservation due to its superlative species richness and endemicity. This region is considered to contain the world's highest number of shallow-water reefbuilding coral species (Veron et al., 2009), reef fishes (Allen, 2008), mangrove biodiversity (Polidoro et al., 2010; Walton et al., 2014), mushroom corals (Hoeksema, 2007), and razor clams (Saeedi et al., 2016), with areas of high biodiversity importance clustered along the southern part of the Philippines, the northeastern part of Malaysian Sabah, the central to eastern part of Indonesia, the eastern part of Papua New Guinea, and the Solomon Islands (Asaad et al., 2018a). Although considerable biodiversity and natural resources data have been collected for the region by scientists and conservation programmes, the data have been scattered and difficult to access. While our prioritization of locations for marine protected areas (MPAs) (Asaad et al., 2018a, b) was successfully collating data of biodiversity features, threats, and environmental variables, this did not make it easily viewable to the public. In addition, a previous online atlas of the CT was developed to support coral reef management and provided biophysical and MPA data from the region (Cros et al., 2014), but was more limited in data on species ranges (e.g., threatened species, endemic species). Thus, updated, more systematic and comprehensive "biodiversity informatics" datasets are required to showcase all of the available data in the region.

This online atlas aims to support the objective of the CTI-CFF initiative (the Coral Triangle Initiative on Coral Reefs, Fisheries, and Food Security). The CTI-CFF initiative is a multilateral partnership of six countries (Indonesia, Malaysia, Papua New Guinea, the Philippines, Solomon Islands, and Timor-Leste) working collaboratively to conserve and sustainably manage their coastal and marine resources (CTI-CFF, 2009). One of the objectives of the Coral Triangle Initiative is to establish and effectively manage MPAs within the region, including a region-wide Coral Triangle MPA system (CTMPAS) (CTI-CFF, 2009). The CTMPAS is a system of MPAs within the CT which includes a range of MPA types and MPA network. This system comprises MPAs that form local ecological and/or governance networks that are nested within larger-scale social networks (CTI-CFF, 2013). Thus, the collections of geospatial data collated in this online GIS database support the development of MPAs and management of marine resources in the region by giving access to policymakers, scientists, and the general public to the most comprehensive, up-to-date and integrated spatial information available for the Coral Triangle.

\section{Methods (Web map design)}

This atlas was developed to interactively display georeferenced biodiversity information on the Coral Triangle (CT): (1) Biodiversity Features; (2) Areas of Importance for 
Biodiversity Conservation; and (3) priority areas for Marine Protected Area (MPA) Network Expansion.

To generate the atlas, related datasets were retrieved from the Coral Triangle database collected in the previous chapters (Asaad et al., 2018a, b). These datasets were collated and developed from various sources (Table 1). For consistency, all the datasets were clipped to the CT region following the implementation boundary of the Coral Triangle Initiative (CTI$\mathrm{CFF}, 2009$ ) with bounding geographic coordinates of $23^{\circ} \mathrm{N}$ to $16^{\circ} \mathrm{S}$ and 90 to $175^{\circ} \mathrm{E}$. All of the data preparations were performed using ArcGIS Desktop 10.5 (ESRI, 2016) and ArcGIS Pro. 2.0 (ESRI, 2017).

The ArcGIS Pro 2.0 was used to deliver and share all of the maps to web feature layers in ArcGIS Online, and design three digital maps using the ArcGIS Online template. Here, a similar template was used for each map to allow map comparisons. These digital maps used a website as an interface and can be accessed from any computer or other electronic device that is connected to the internet using a standard browser (e.g., Internet Explorer, Google Chrome, or Safari). The maps were hosted by ArcGIS Online in a cloud service provided by the Amazon EC2 (Elastic Compute Cloud).

Each atlas consists of different feature layers:

- The map of "biodiversity features" is comprised of 10 feature layers, including (a) seven layers of biodiversity features (biogenic habitat, species richnessranges, species richness-occurrence, species of conservation concern, species of restricted range, important areas for sea turtles and habitat rugosity; (b) two types of threat (anthropogenic and climate change); and (c) a composite of 16 environmental variables (Table 1).

- The map of "areas of importance for biodiversity conservation" is comprised of two feature layers: (a) regional biodiversity hotspots; and (b) sites of biodiversity importance (Table 1).

- The map of "priority areas for marine protected area network expansion" consists of nine feature layers: (a) three layers highlighting recommended priority areas for expansion of the Coral Triangle MPA network under scenarios of regional expansion to encompass $10 \%, 20 \%$, and $30 \%$ of CT marine area within the network; and (b) six layers showing priority areas for expansion of individual CT country MPA networks for Indonesia, Malaysia, the Philippines, Papua New Guinea, Solomon Islands and Timor-Leste. Each layer of the national priority areas is comprised of three scenarios of MPA expansion $(10 \%, 20 \%, 30 \%)$ (Table 1).

- Three base layers are included for each web map: existing marine protected areas, national exclusive economic zones (EEZs) and country boundaries (Table 1).

To access the maps, a gallery-like web front page was developed with a hyperlink to each digital map. To allow users to explore a wide variety of functions offered by the maps, 15 types of widgets (a control element in a graphical user interface) were embedded (e.g., Home button, Layer list, Select, Draw; see Table 2). A documentation website was developed to define the map's objectives, datasets, classifications, and original citations of the sources.

\section{Results}

The atlas of the Coral Triangle is an online GIS database, and can be assessed through a web front-page (http://www. marine.auckland.ac.nz/CTMAPS; Fig. 1). These geospatial datasets were built on three interlinked themes: (a) Biodiversity Features (http://marine.auckland.ac.nz/CT_Biodiversity; Fig. 2), which provides comprehensive data on the region's marine protected areas, biodiversity features, threats, and environmental characteristics; (b) Areas of Importance for Biodiversity Conservation (http://www.marine.auckland.ac. nz/CT_Priority), which provides spatial distributions of areas of high biodiversity conservation value; and (c) priority areas for Coral Triangle Marine Protected Area (MPA) Network Expansion (http://www.marine.auckland.ac. nz/CT_MPA), which provides spatial information of priority areas for potential expansion of the existing MPA network. Relevant information on the maps can be accessed through an accompanying documentation website (https://sites.google. com/view/coral-triangle-digital-map).

\section{Data availability}

The "Data availability" is covered in the results section.

\section{Discussion}

The atlas of the Coral Triangle showcases all of the currently available marine biodiversity conservation data for the Coral Triangle region. They are derived from the most comprehensive biodiversity conservation datasets for the region, featuring spatial information for the region based on their habitat and species-specific attributes, vulnerabilities to threats, and environmental characteristics. The maps also include a set of data to indicate areas of importance for biodiversity conservation, existing MPAs, and priority areas of the designation of new MPAs or MPA expansion in the Coral Triangle, showing priorities for biodiversity conservation at both regional and national scales.

Collating and comparing datasets from different sources presented a number of challenges. To have a consistent format and spatial attributes, all datasets were converted into a vector format (i.e., lines or polygon shape) and standardized geographic projections. To reduce data discrepancy, the biodiversity feature datasets were classified using equal interval classes based on their biodiversity values. The datasets were then grouped into themes (biodiversity features, areas 
Table 1. Coral Triangle datasets specifications.

\begin{tabular}{|c|c|c|c|c|c|}
\hline & $\begin{array}{l}\text { Data } \\
\text { layer }\end{array}$ & Feature & $\begin{array}{l}\text { Type, spatial } \\
\text { resolution, } \\
\text { class }\end{array}$ & Descriptions & Sources \\
\hline \multicolumn{6}{|c|}{ Base Layers } \\
\hline a. & $\begin{array}{l}\text { Coral } \\
\text { Triangle } \\
\text { boundary }\end{array}$ & $\begin{array}{l}\text { Generated from } \\
\text { the Coral Triangle } \\
\text { Initiative } \\
\text { implementation } \\
\text { boundary }\end{array}$ & Polygon & $\begin{array}{l}\text { The boundary covers the full exclusive } \\
\text { economic zones (EEZs) of Indonesia, } \\
\text { Malaysia, Papua New Guinea, } \\
\text { the Philippines, Solomon Islands, } \\
\text { and Timor-Leste, and includes } \\
\text { the EEZs of two additional nations: } \\
\text { Brunei Darussalam and Singapore. }\end{array}$ & VLIZ (2014) \\
\hline b. & $\begin{array}{l}\text { Country } \\
\text { boundary }\end{array}$ & $\begin{array}{l}\text { Internal boundary } \\
\text { of Coral Triangle } \\
\text { countries }\end{array}$ & Polyline & $\begin{array}{l}\text { The EEZs and internal boundaries } \\
\text { are indicative only, and a dispute } \\
\text { over boundaries exists. }\end{array}$ & VLIZ (2014) \\
\hline c. & $\begin{array}{l}\text { Marine } \\
\text { protected } \\
\text { areas (MPAs) } \\
\text { coverage }\end{array}$ & $\begin{array}{l}\text { Coverage of } \\
678 \text { units of } \\
\text { MPA }\end{array}$ & Polygon & $\begin{array}{l}\text { The layers' attribute table provides } \\
\text { detailed information following its } \\
\text { native sources (WDPA, CTAtlas) } \\
\text { (e.g., information about name, } \\
\text { local name, designation type, } \\
\text { IUCN category, coverage; IUCN and } \\
\text { UNEP-WCMC, 2016; Cros et al., 2014) } \\
\text { with amendment and adjustment from } \\
\text { local sources (Indonesian database). } \\
\text { To allow simple indexing, a new CT MPAs } \\
\text { ID format (MPA_ID) is introduced. } \\
\text { The new ID consists of } 10 \text { digits } \\
\text { (C IC XXXX yyy): } \\
\text { - C = Country; } 1=\text { Indonesia, } 2=\text { Malaysia, } \\
3=\text { Philippines, } 4=\text { Papua New Guinea, } \\
5=\text { Solomon Islands, and } 6=\text { Timor-Leste } \\
\text { - IC = IUCN MPAs category; } \\
\text { strict nature reserve (1a = } 11,1 \mathrm{~b}=12), \\
\text { national park (20), habitat and } \\
\text { species management Areas ( } 40), \\
\text { protected landscape/seascape }(50), \text { and } \\
\text { managed resource protected areas }(60) \\
\text { - XXXX = establishment year (e.g., 1980) } \\
\text { - yyy = Number; ordered based on their } \\
\text { establishment year }\end{array}$ & $\begin{array}{l}\text { IUCN and } \\
\text { UNEP-WCMC (2016), } \\
\text { Cros et al. (2014), } \\
\text { MoF-MoMAF (2010), } \\
\text { MoMAF (2016) }\end{array}$ \\
\hline \multicolumn{6}{|c|}{ Biodiversity features } \\
\hline a. & $\begin{array}{l}\text { Biogenic } \\
\text { Habitat }\end{array}$ & $\begin{array}{l}\text { Refers to the habitats } \\
\text { that are created } \\
\text { by plants and } \\
\text { animals. } \\
\text { Spatial distribution } \\
\text { of coral reef, seagrass, } \\
\text { and mangroves. }\end{array}$ & $\begin{array}{l}\text { Grid square } \\
\text { cells; } 5 \mathrm{~km} ; \\
3 \text { classes }\end{array}$ & $\begin{array}{l}\text { Calculated based on } \\
\text { the number of biogenic } \\
\text { habitat present } \\
\text { in each cell. } \\
\text { Cell values ranged 1-3. }\end{array}$ & $\begin{array}{l}\text { UNEP-WCMC } \\
\text { et al. (2010), } \\
\text { Giri et al. } \\
\text { (2011a, b), } \\
\text { UNEP-WCMC and } \\
\text { Short (2005) }\end{array}$ \\
\hline b. & $\begin{array}{l}\text { Species } \\
\text { richness - } \\
\text { ranges }\end{array}$ & $\begin{array}{l}\text { A modeled geographic } \\
\text { distribution of } \\
10672 \text { species } \\
\text { ranges. }\end{array}$ & $\begin{array}{l}\text { Grid square } \\
\text { cells; } 50 \mathrm{~km} \text {; } \\
10 \text { classes }\end{array}$ & $\begin{array}{l}\text { Calculated based on the number } \\
\text { predicted species in each cell. } \\
\text { The number of predicted species } \\
\text { per cell ranged } 0-5509 \text {. }\end{array}$ & $\begin{array}{l}\text { Kaschner } \\
\text { et al. (2016) }\end{array}$ \\
\hline c. & $\begin{array}{l}\text { Species } \\
\text { richness - } \\
\text { occurrence }\end{array}$ & $\begin{array}{l}\text { The occurrence records } \\
\text { of } 19251 \text { species. }\end{array}$ & $\begin{array}{l}\text { Grid square } \\
\text { cells; } 50 \mathrm{~km} \text {; } \\
10 \text { classes }\end{array}$ & $\begin{array}{l}\text { Based on the index of expected } \\
\text { species richness of } \mathrm{ES}_{50} \\
\text { (estimated species in } \\
\text { random } 50 \text { samples). }\end{array}$ & OBIS (2015) \\
\hline d. & $\begin{array}{l}\text { Species of } \\
\text { conservation } \\
\text { concern }\end{array}$ & $\begin{array}{l}\text { The occurrence records of } \\
834 \text { species of conservation } \\
\text { concern (Bony fish, anthozoans, } \\
\text { elasmobranchs, mammals, } \\
\text { and mollusks). }\end{array}$ & $\begin{array}{l}\text { Grid square } \\
\text { cells; } 50 \mathrm{~km} \\
10 \text { classes }\end{array}$ & $\begin{array}{l}\text { Based on the index of expected } \\
\text { species richness of } \mathrm{ES}_{35} \\
\text { (estimated species in } \\
\text { random } 50 \text { samples). }\end{array}$ & $\begin{array}{l}\text { OBIS (2015), } \\
\text { Froese and } \\
\text { Pauly (2016), } \\
\text { IUCN (2015), } \\
\text { UNEP-WCMC (2015) }\end{array}$ \\
\hline e. & $\begin{array}{l}\text { Species of } \\
\text { restricted- } \\
\text { range }\end{array}$ & $\begin{array}{l}\text { The distribution of } \\
373 \text { restricted-range } \\
\text { reef fish species. }\end{array}$ & $\begin{array}{l}\text { Grid square } \\
\text { cells; } 5 \mathrm{~km} ; \\
10 \text { classes }\end{array}$ & $\begin{array}{l}\text { Calculated based on the number of } \\
\text { of species present in each cell. } \\
\text { Cell values ranged } 1-101 \text {. }\end{array}$ & $\begin{array}{l}\text { Allen (2008), } \\
\text { Allen and } \\
\text { Erdmann (2013). }\end{array}$ \\
\hline
\end{tabular}


Table 1. Continued.

\begin{tabular}{|c|c|c|c|c|c|}
\hline & $\begin{array}{l}\text { Data } \\
\text { layer }\end{array}$ & Feature & $\begin{array}{l}\text { Type, spatial } \\
\text { resolution, } \\
\text { class }\end{array}$ & Descriptions & Sources \\
\hline f. & $\begin{array}{l}\text { Important } \\
\text { areas for } \\
\text { sea turtle }\end{array}$ & $\begin{array}{l}\text { Nesting sites and } \\
\text { migratory route of } \\
\text { six species } \\
\text { (2055 records). }\end{array}$ & $\begin{array}{l}\text { Grid square } \\
\text { cells; } 5 \mathrm{~km} \text {; } \\
3 \text { classes }\end{array}$ & $\begin{array}{l}\text { The richness calculated based on } \\
\text { the number of sea turtle species } \\
\text { present in each cell (i.e., 1, 2, 3). }\end{array}$ & $\begin{array}{l}\text { MoF-MoMAF (2010), } \\
\text { OBIS (2015) }\end{array}$ \\
\hline g. & $\begin{array}{l}\text { Habitat } \\
\text { rugosity }\end{array}$ & $\begin{array}{l}\text { A vector ruggedness } \\
\text { measure (VRM) of } \\
\text { benthic terrain, } \\
\text { generated from } \\
\text { bathymetric data. }\end{array}$ & $\begin{array}{l}\text { Grid square } \\
\text { cells; } 50 \mathrm{~km} \text {; } \\
10 \text { classes }\end{array}$ & $\begin{array}{l}\text { The VRM index ranged from } 0.1 \\
\text { (areas with low terrain } \\
\text { variations) to } 0.9 \text { (areas } \\
\text { with high terrain variations). }\end{array}$ & $\begin{array}{l}\text { Basher et al. } \\
(2014) \text {, } \\
\text { Wright et al. } \\
(2012)\end{array}$ \\
\hline h. & $\begin{array}{l}\text { Anthropogenic } \\
\text { pressure } \\
\text { (AP) }\end{array}$ & $\begin{array}{l}\text { Spatial distribution } \\
\text { of AP on marine } \\
\text { environments. }\end{array}$ & $\begin{array}{l}\text { Grid square } \\
\text { cells; } 5 \mathrm{~km} \text {; } \\
10 \text { classes }\end{array}$ & $\begin{array}{l}\text { The cumulative impact of } 19 \text { different } \\
\text { types of anthropogenic stressors. } \\
\text { The AP value ranged } 0-15.4 \text {, } \\
\text { indicating areas from low to } \\
\text { high human-induced pressure. }\end{array}$ & $\begin{array}{l}\text { Halpern et al. } \\
(2008,2015 a, b)\end{array}$ \\
\hline i. & $\begin{array}{l}\text { Climate } \\
\text { change } \\
\text { pressure }\end{array}$ & $\begin{array}{l}\text { Spatial distribution of sea } \\
\text { surface thermal stress level } \\
\text { (the average of degree } \\
\text { heating weeks, DHW) } \\
\text { from } 2006 \text { to } 2099 \text {. }\end{array}$ & $\begin{array}{l}\text { Grid square } \\
\text { cells; } 5 \mathrm{~km} \text {; } \\
10 \text { classes }\end{array}$ & $\begin{array}{l}\text { The projected thermal stress index } \\
\text { ranged } 5.6-20.2 \text {, indicating areas } \\
\text { from low to high vulnerability } \\
\text { to climate change. }\end{array}$ & $\begin{array}{l}\text { Van Hooidonk } \\
\text { et al. (2016) }\end{array}$ \\
\hline $\mathrm{j}$. & $\begin{array}{l}\text { Environmental } \\
\text { Variables }\end{array}$ & $\begin{array}{l}\text { Spatial distribution of } \\
\text { environmental variables } \\
\text { (physical, biochemical, } \\
\text { and nutrients). }\end{array}$ & $\begin{array}{l}\text { Point; } 50 \mathrm{~km} \text {; } \\
10 \text { classes }\end{array}$ & $\begin{array}{l}\text { Composite point features of } \\
16 \text { environmental variables, } \\
\text { i.e., depth, slope, land distance, } \\
\text { temperature, surface current, } \\
\text { salinity, wind speed, tide, } \\
\text { primary productivity, photosynthetically } \\
\text { active radiation (PAR), chlorophyll } a \text {, } \\
\text { pH, dissolved oxygen, nitrate, silicate, } \\
\text { and calcite. }\end{array}$ & $\begin{array}{l}\text { Basher et al. } \\
(2014)\end{array}$ \\
\hline \multicolumn{6}{|c|}{ Areas of Importance for Biodiversity Conservation } \\
\hline a. & $\begin{array}{l}\text { Regional } \\
\text { biodiversity } \\
\text { hotspots }\end{array}$ & $\begin{array}{l}\text { Clusters of areas } \\
\text { of biodiversity } \\
\text { importance. }\end{array}$ & $\begin{array}{l}\text { Grid square cells; } \\
55 \mathrm{~km} \text {; three classes } \\
\text { of hotspots (high, } \\
\text { medium, and low) } \\
\text { and one class was not } \\
\text { significant }\end{array}$ & $\begin{array}{l}\text { Developed based on the multi-criteria analysis } \\
\text { to five ecological criteria (sensitive habitat, } \\
\text { species richness, the presence of species of } \\
\text { conservation concern, the occurrence of } \\
\text { restricted-range species, areas of importance } \\
\text { for particular life history stages). } \\
\text { Analyzed based on the spatial patterns of data } \\
\text { using the hotspots analysis tool in ArcGIS. } \\
\text { The analysis clustered the cells from hotspot } \\
\text { (high-score cells) to coldspots (low-score cells). }\end{array}$ & $\begin{array}{l}\text { Asaad et al. } \\
(2018 \mathrm{a})\end{array}$ \\
\hline b. & $\begin{array}{l}\text { Sites of } \\
\text { biodiversity } \\
\text { importance }\end{array}$ & $\begin{array}{l}\text { Distribution of } \\
\text { sites of areas of } \\
\text { biodiversity } \\
\text { importance. }\end{array}$ & $\begin{array}{l}\text { Grid square cells; } \\
55 \mathrm{~km} \text {; five classes } \\
\text { (high, medium-high, } \\
\text { medium, medium-low, } \\
\text { and low) }\end{array}$ & $\begin{array}{l}\text { Developed based on the similar ecological } \\
\text { criteria to those used in the biodiversity } \\
\text { hotspots region analysis. } \\
\text { While the hotspots analysis identified clustered } \\
\text { areas of biodiversity importance. The site-based } \\
\text { analysis identifies specific sites of highest } \\
\text { biodiversity importance by analyzing } \\
\text { the biodiversity score of each cell. } \\
\text { The higher the score, the higher their } \\
\text { biodiversity importance. }\end{array}$ & $\begin{array}{l}\text { Asaad et al. } \\
(2018 \mathrm{a})\end{array}$ \\
\hline
\end{tabular}

of important for biodiversity conservation, and priority areas for MPA network expansion). Each theme consists of sub-themes, to promote simple indexing, retrieving, and data management. Here, this study showed that for conducting a biodiversity conservation programme, biodiversity data are indeed available, yet they are frequently scattered and not always easily accessed. Using an approach such as the one we describe here, these widely scattered datasets can be integrated and amalgamated to perform such complex tasks as biodiversity prioritization analysis (Asaad et al., 2018a, b). 
Table 1. Continued.

\begin{tabular}{|c|c|c|c|c|c|}
\hline & $\begin{array}{l}\text { Data } \\
\text { layer }\end{array}$ & Feature & $\begin{array}{l}\text { Type, spatial } \\
\text { resolution, } \\
\text { class }\end{array}$ & Descriptions & Sources \\
\hline \multicolumn{6}{|c|}{ Marine Protected Area (MPA) Network Expansion } \\
\hline a. & $\begin{array}{l}\text { Regional } \\
\text { priority } \\
\text { areas }\end{array}$ & $\begin{array}{l}\text { Spatial distribution of } \\
\text { regional priority areas } \\
\text { with three expansion } \\
\text { scenario layers: } \\
10 \%, 20 \% \text {, and } 30 \% \text {. }\end{array}$ & $\begin{array}{l}\text { Grid square cells; } \\
0.5 \mathrm{~km}\end{array}$ & $\begin{array}{l}\text { Prioritization analyses were performed using } \\
\text { Zonation tools to analyze the proportions of } \\
\text { the CT region placed into an MPA network } \\
\text { (e.g., expansion of the MPA network from existing } \\
\text { coverage to } 10 \%, 20 \% \text {, and } 30 \% \text { of } \\
\text { the exclusive economic zone (EEZ) area). } \\
\text { The prioritization scenarios were based on seven } \\
\text { sets of biodiversity features (biogenic habitat, } \\
\text { habitat rugosity, species richness, distribution of } \\
\text { threatened and endemic species, areas important for } \\
\text { sea turtle); two types of threat (anthropogenic and } \\
\text { climate change induced pressure); and } \\
\text { the coverage of the existing MPA network. } \\
\text { Regional analyses were performed for the full CT EEZ region. }\end{array}$ & $\begin{array}{l}\text { Asaad et al } \\
\text { (2018b) }\end{array}$ \\
\hline b. & $\begin{array}{l}\text { National } \\
\text { Priority } \\
\text { Areas }\end{array}$ & $\begin{array}{l}\text { Spatial distribution of } \\
\text { national priority areas with } \\
\text { six layers of scenarios } \\
\text { representing national MPA } \\
\text { network expansion for Indonesia, } \\
\text { Malaysia, the Philippines, } \\
\text { Papua New Guinea, Solomon } \\
\text { Islands and Timor-Leste. }\end{array}$ & $\begin{array}{l}\text { Grid square cells; } \\
0.5 \mathrm{~km}\end{array}$ & $\begin{array}{l}\text { Developed based on the same approach as the regional } \\
\text { priority areas. } \\
\text { National analyses were performed individually on } \\
\text { each CT country's national EEZ. } \\
\text { Each layer consisted of three scenarios of MPA expansion } \\
(10 \%, 20 \%, 30 \%)\end{array}$ & $\begin{array}{l}\text { Asaad et al } \\
\text { (2018b) }\end{array}$ \\
\hline
\end{tabular}

\section{Atlas of biodiversity conservation of the Coral Triangle}

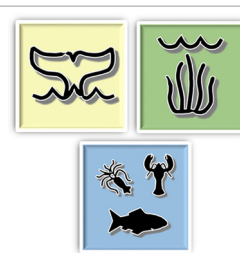

Web mapping application

Biodiversity features

Map of marine protected areas, biodiversity features, threats and environmental variables in the Coral Triangle.

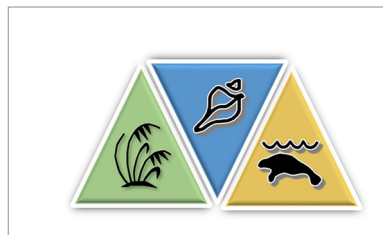

Web mapping application

Areas of importance for biodiversity conservation

Map of areas of

biodiversity importance in the Coral Triangle, comprised of :

(1) clustered areas of

biodiversity hotspots;

(2) site-based areas of

biodiversity importance.

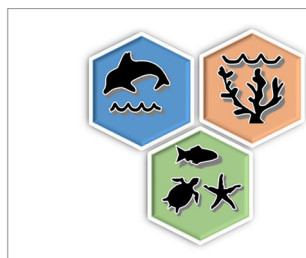

Web mapping application

MPA network expansion

Map of priority areas of marine protected area (MPA) network expansion in the Coral Triangle region, comprised of:

(1) regional priority areas;

(2) national priority areas.

Figure 1. Coral Triangle web-mapping application front-page. This gallery-like interface provides a hyperlink to access each of the maps of the Coral Triangle Atlas. 
Table 2. Widgets provided for the Coral Triangle Atlas.

\begin{tabular}{|c|c|c|}
\hline Icon & Widget & Functions \\
\hline \multicolumn{3}{|c|}{ Controller widgets (header panels) } \\
\hline & About & Displays general information about the apps, including purposes, data layers, and links to the documentation files. \\
\hline & Basemap gallery & Provides a gallery of base maps and allows users to select their preference. \\
\hline & Layer list & Presents a list of layers in the map and allows users to interactively choose layers that need to be activated. \\
\hline \multicolumn{3}{|r|}{ Each layer has a checkbox and allows users to change the order of the layers in the map. } \\
\hline 二 & Legend & Displays a legend of active layers showing in the map. \\
\hline \multicolumn{3}{|c|}{ Placeholder widgets (on-screen panel) } \\
\hline :日 & Swipe & $\begin{array}{l}\text { Displays thumbnail views of different layers on top of the map to enable a quick comparison of the content } \\
\text { of different layers. Here we used the spyglass view model. }\end{array}$ \\
\hline & Draw & $\begin{array}{l}\text { Enables users to create and draw graphics (sketches) on the map. There are } 11 \text { feature creation tools (point, } \\
\text { line, polyline, freehand, triangle, rectangle, circle, ellipse, polygon, freehand polygon, and text). } \\
\text { It also displays measurements of the drawn features (lengths, areas, and perimeters). }\end{array}$ \\
\hline & Measurement & $\begin{array}{l}\text { Provides tools to measure areas (polygons), to calculate distance (line), and to show geographic } \\
\text { coordinates (point). Each measurement can be displayed in a variety of measurement units } \\
\text { (i.e., metric and imperial system). }\end{array}$ \\
\hline 范: & Print & $\begin{array}{l}\text { Enables printing of the map. This widget allows users to choose the map layout (and format e.g., pdf, jpg, gif) } \\
\text { and an advanced option to select map scale, size, and printing quality. }\end{array}$ \\
\hline & Select & $\begin{array}{l}\text { Provides interactive tools to select features and perform tasks on the selected features. There are four options to draw } \\
\text { a selection: select by rectangle, polygon, circle, and line. The selected features actions can be explored through } \\
\text { the following functions. } \\
\text { - Display tasks: zoom to-, pan to- and flash. } \\
\text { - Export: to CSV files, to feature collections, and to GeoJSON (export to a features.geojson file). } \\
\text { - Statistics: display simple statistics of the selected features (sum, max, min, average, standard deviation). } \\
\text { - Save to My Content: save selected features to My Content page in ArcGIS Online or ArcGIS Enterprises. } \\
\text { - Create layer: enables to create layer for a single or selected feature. } \\
\text { - View in attribute table: previews the attribute table of the selected features. }\end{array}$ \\
\hline \multicolumn{3}{|c|}{ Off-panel widgets } \\
\hline & Home button & Displays the initial extent of the map. The bounding coordinates of the map are from $23^{\circ} \mathrm{N}$ to $16^{\circ} \mathrm{S}$ and 90 to $175^{\circ} \mathrm{E}$. \\
\hline$\equiv$ & Attribute table & $\begin{array}{l}\text { Shows a tabular view of operational layers' attributes. Located at the bottom of the map, and can be configured to } \\
\text { display selected features, zoom to and filter the table based on the map extent. }\end{array}$ \\
\hline & Coordinate & $\begin{array}{l}\text { Displays coordinates of the map ( } x \text { and } y \text { values). Shows the coordinates in the WGS } 1984 \text { Mercator Auxiliary } \\
\text { Sphere (WKID 3857) projection. Located in the lower-left corner of the map. }\end{array}$ \\
\hline 傿 & Scale bar & Shows a scale bar of the map. Updated dynamically based on map's scale. Located in the lower-left corner of the map. \\
\hline 4 & My location & Displays the physical location and zooms the map to the users location. \\
\hline \pm & Zoom slider & Provides an interactive zoom for the map display. \\
\hline
\end{tabular}




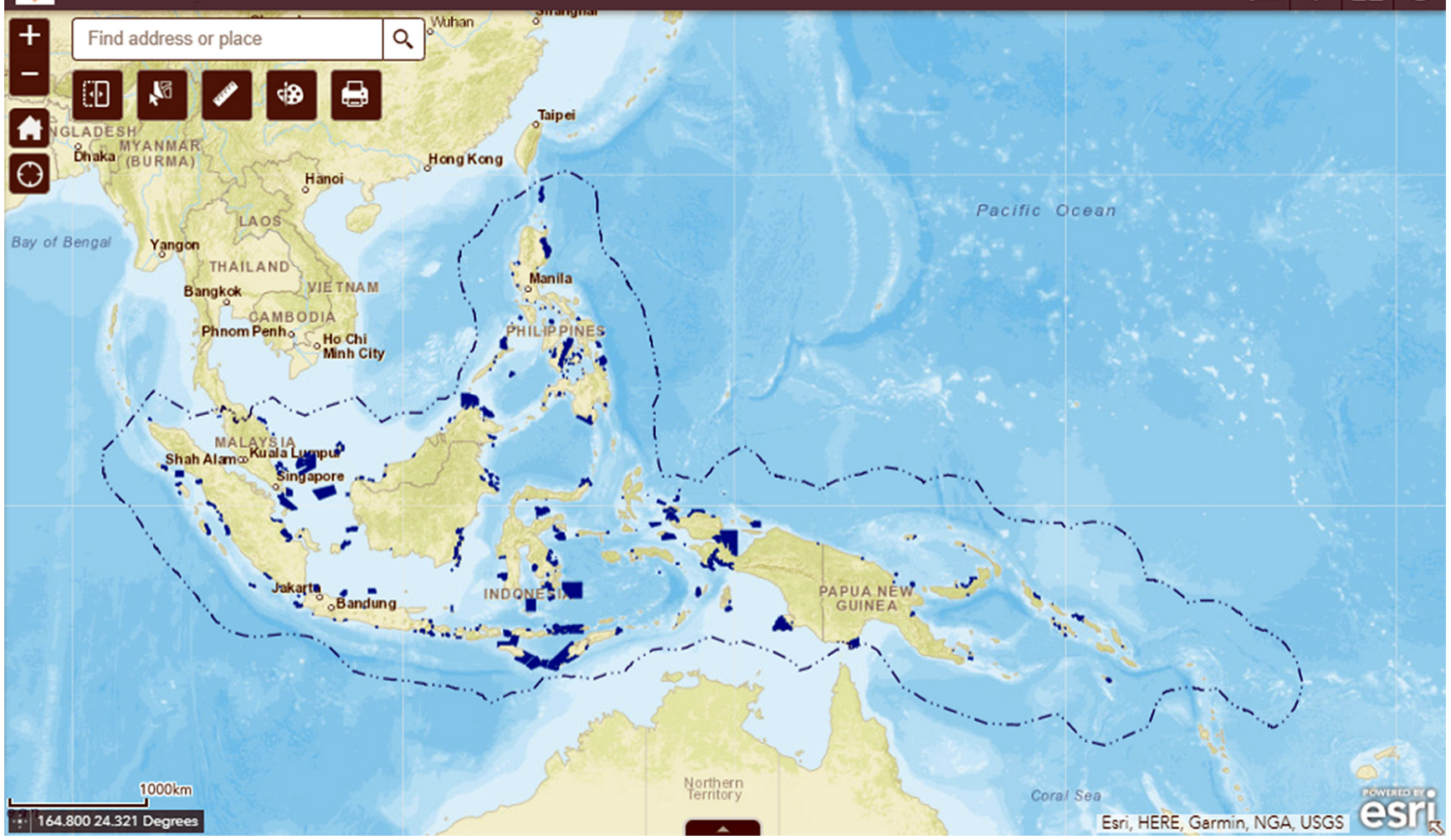

Figure 2. The interface of the Atlas of the Biodiversity Conservation of the Coral Triangle. The Coral Triangle countries' EEZs (blue-dashed line) and distribution of marine protected areas (blue) are indicated.

This study developed an interactive web application that featured maps and geospatial contents using a configurable template provided by ArcGIS Online. This approach reduces the complexity of code writing, website programming, and other technical knowledge needed to create a web map. We opted to use accessible and less technical tools, to show that even with limited skills in internet GIS and web development, scientific communities have an opportunity to develop geospatial tools to support biodiversity conservation. Replication of this type of approach in the other regions is important as there is a continuing trend of biodiversity loss and limited resources are available to protect all of the important biodiversity.

This atlas was designed to enable an efficient decisionmaking process and to engage a wider stakeholder audience. To support these objectives, all of the datasets were featured in a format that can be overlaid and visualized directly using a standard web browser. This web browser platform facilitates interactive access and examination of the data without the need for expensive GIS software. The spatial information in each dataset can be extracted through (a) intuitively hovering the mouse over and selecting a feature; (b) using "select" widgets and exporting the selected features to preferred data formats; and (c) reproducing the maps in suitable graphic formats using "print" widgets. The "select" widgets provide a range of export formats, ranging from a generic "commaseparated values (CSV)" file that stores tabular data in plain text, to a "Geo JavaScript Object Notation (GeoJSON)" file, an open standard format designed for representing simple geographical features, along with their non-spatial attributes. The "print" widgets provide an option to reproduce maps in a variety of formats such as pdf, jpeg, and gif, which facilitate inclusion in presentations or embedding of maps in reports. To enable and encourage data explorations, the "select" widgets were supplied with functions to conduct simple statistical analysis (e.g., sum, average, maximum, minimum, and standard deviation of selected data).

This atlas could be linked to the previous Coral Triangle Atlas developed by Cros et al. (2014) that is currently managed by the Coral Triangle Initiative Secretariat. These atlases are complementary in design and applications and may provide options to stakeholders to retrieve reliable Coral Triangle data. Here, our atlas provides a supplement and enriches the previous atlas by providing access to explore areas of biodiversity importance within the coral Triangle and a set of priority areas to designate new MPA within the region. We integrated ecological and biological datasets following standard ecological criteria to identify areas for biodiversity conservation (Asaad et al., 2016). Our "Biodiversity Features" datasets are comprised of biogenic habitat, species richness- 
occurrences, species richness-ranges, species of conservation concern, restricted range species, areas important for life history stage of species, and habitat rugosity. The datasets are ready to use and are applicable for identifying priority areas for biodiversity conservation. In addition, this atlas included datasets of threats, comprised of present anthropogenic and projected climate change induced pressures. Knowledge of threat level provides key information for developing alternative marine spatial planning and management strategies, e.g., enforcement, habitat restoration, and mitigation (Green et al., 2009; McLeod et al., 2010; Maynard et al., 2015). Furthermore, this atlas also provided data for 16 environmental variables (including physical, chemical, and oceanographic variables). As such, this atlas offers an opportunity to explore the relationship between biologically diverse areas and underlying physical and chemical parameters, as well as the relationship with potential pressure factors.

In this atlas, the biogenic habitat distribution map was retrieved from three types of coastal habitat (coral reefs, seagrass, and mangroves) that may generate a bias towards coastal regions. A detailed habitat map and a defined list of habitat types are needed to fully evaluate the ecological and biological significance of the marine area. In addition, this atlas focuses on the biodiversity features within the economic exclusive zones (EEZs) of the Coral Triangle countries. There are vast resources found outside the EEZ including some of the most productive ecosystems (e.g., seamounts, hydrothermal vents), rare and unique species, and migratory routes of endangered marine species. Thus, biodiversity data of areas beyond national jurisdictions potentially complement the EEZ data to improve and develop a comprehensive biodiversity conservation programme in the region.

There are opportunities to improve and advance the geospatial functionality of this Coral Triangle atlas. An envisioned future version of this atlas is a dynamic online database which provides tools to add, upload and store new biodiversity data (e.g., species occurrence data). The growing trend of citizen science opens an opportunity to collect and integrate potentially massive amounts of data to fill gaps in the biodiversity data records. In addition, the availability of options for running online spatial analysis tasks such as identifying priority areas or delineating protected reserves in a defined geographic area or for a specific dataset may offer an opportunity to further enhance the performance of this atlas.

This atlas may be used by initiatives such as IODEICAN (International Coastal Atlas Network), the Global Health Ocean Index (http://www.oceanhealthindex.org/), the GEO-Marine Biodiversity Observation Network (https:// boninabox.geobon.org/), UNEP-WCMC Network (http:// data.unep-wcmc.org/), and others network related to the UN SDG Goal 14 and the upcoming UN Decade of Ocean Science. This type of atlas fills a regional gap in data within such global initiatives and provides more detailed informa- tion that can be used to develop a region-based biodiversity conservation strategy.

The collections of geospatial data collated on this online GIS database are aimed to give access to policymakers, scientific communities, and the general public full access to the most comprehensive, up-to-date, and integrated spatial information available for the Coral Triangle. This atlas presents representative information to promote a better understanding of important areas for biodiversity conservation and the application of marine biodiversity informatics to support conservation prioritization in the Coral Triangle region.

Author contributions. IA conceived the research ideas, designed the methodology, developed the web GIS applications, and wrote the manuscript. CJL gave advice and guidance in the study design, interpretation of the research, and reviewed the manuscript for scientific rigor and readability. MVE gave advice and guidance in the study design, interpretation of the research, and reviewed the manuscript for scientific rigor and readability. MJC gave advice and guidance in the study design, interpretation of the research, and reviewed the manuscript for scientific rigor and readability.

Competing interests. The authors declare that they have no conflict of interest.

Acknowledgements. Irawan Asaad is supported by the New Zealand Aid Programme through the New Zealand ASEAN Scholarship. We would like to thank Dr Tilmann Steinmetz (NIWA - Wellington), Keith Van Graafeiland (ESRI - Redlands), Graeme Glen, and Robert Carter (UoA - Auckland) for their technical assistance in developing this online atlas.

Edited by: Falk Huettmann

Reviewed by: Alan White, Simon Pittman, and one anonymous referee

\section{References}

Allen, G. R.: Conservation hotspots of biodiversity and endemism for Indo-Pacific coral reef fishes, Aquat. Conserv., 18, 541-556, 2008.

Allen, G. R. and Erdmann, M. V.: Reef fishes of the East Indies. Mobile Application Software, Version 1.1 (Rev.10.2016), available at: https://geo.itunes.apple.com/us/ app/reef-fishes-east-indies-vol./id705188551 ?mt=8(9). (last access: 15 June 2016), 2013.

Alsheikh-Ali, A. A., Qureshi, W., Al-Mallah, M. H., and Ioannidis, J. P.: Public availability of published research data in high-impact journals, PloS One, 6, e24357, https://doi.org/10.1371/journal.pone.0024357, 2011.

Asaad, I., Lundquist, C. J., Erdmann, M. V., and Costello, M. J.: Ecological criteria to identify areas for biodiversity conservation, Biol. Conserv., 213, 309-316, https://doi.org/10.1016/j.biocon.2016.10.007, 2016. 
Asaad, I., Lundquist, C. J., Erdmann, M. V., and Costello, M. J.: Delineating priority areas for marine biodiversity conservation in the Coral Triangle, Biol. Conserv., 222, 198-211, https://doi.org/10.1016/j.biocon.2018.03.037, 2018a.

Asaad, I., Lundquist, C. J. L., Erdmann, M. V. E., Hooidonk, V., Van Hooidonk, R., and Costello, M. J. : Designating spatial priorities for marine biodiversity conservation in the Coral Triangle, Frontiers In Marine Science, 5, 400, https://doi.org/10.3389/fmars.2018.00400, 2018b.

Basher, Z., Bowden, D. A., and Costello, M. J.: Global Marine Environment Datasets (GMED)-World Wide Web electronic publication, Ver. 1.0 (Rev.01.2014), available at: http://gmed.auckland. ac.nz (last access: 1 June 2016), 2014.

Barale, V., Assouline, M., Dusart, J., and Gaffuri, J.: The European atlas of the seas: relating natural and socio-economic elements of coastal and marine environments in the European Union, Mar. Geod., 38, 79-88, 2015.

Bisby, F. A.: The quiet revolution: biodiversity informatics and the internet, Science, 289, 2309-2312, 2000.

Clarke, K. C.: Maps \& Web Mapping, Pearson Education, New York, 2014.

Costello, M. J.: Motivating online publication of data, BioScience, 59, 418-427, 2009.

Costello, M. J. and Vanden Berghe, E.: 'Ocean biodiversity informatics'; A new era in marine biology research and management, Mar. Ecol. Prog. Ser., 316, 203-214, https://doi.org/10.3354/Meps316203, 2006.

Costello, M. J., Michener, W. K., Gahegan, M., Zhang, Z.-Q., and Bourne, P. E.: Biodiversity data should be published, cited, and peer-reviewed, Trends Ecol. Evol., 28, 454-461, 2013.

Cros, A., Fatan, N.A., White, A., Teoh, S.J., Tan, S., Handayani, C., Huang, C., Peterson, N., Li, R.V., Siry, H.Y., Fitriana, R., Gove, J., Acoba, T., Knight, M., Acosta, R., Andrew, N., and Beare, D.: The Coral Triangle Atlas; An Integrated Online Spatial Database System for Improving Coral Reef Management, Plos One, 9, e96332, https://doi.org/10.1371/journal.pone.0096332, 2014.

CTI-CFF: The Regional Plan of Action of the Coral Triangle on Coral Reefs, Fisheries and Food Security (CTI-CFF) Initiative, The secretariat of CTI-CFF Initiative, Jakarta, Indonesia, 2009.

CTI-CFF: Coral Triangle Marine Protected Area System Framework and Action Plan, CTI-CFF, United States Agency for International Development Coral Triangle Support Partnership and US National Oceanic and Atmospheric Administration, Cebu City, The Philippines, 2013.

ESRI: ArcGIS Desktop Ver.10.5, ESRI, Redlands, CA, 2016.

ESRI: ArcGIS Pro Ver. 2.0, ESRI, Redlands, CA, 2017.

Froese, R. and Pauly, D.: FishBase, World Wide Web electronic publication, Ver. (06/2016), available at: http://www.fishbase. org, last access: 1 June 2016.

Fu, P. and Sun, J.: Web GIS; Principles and applications, ESRI Press, Redlands, CA, 2010.

GBIF: https://www.gbif.org, last access: 1 April 2018.

GBIF: Darwin Core Archives - How-to Guide, Ver. 1 Released on 1 March 2010, contributed by: Remsen, D., Braak, K., Döring, M., Robertson, T., Global Biodiversity Information Facility, Copenhagen, 21 pp., 2010.

Giri, C., Ochieng, E., Tieszen, L., Zhu, Z., Singh, A., Loveland, T., Masek, J., and Duke, N.: Status and distribution of mangrove forests of the world using earth observation satellite data, Global Ecol. Biogeogr., 20, 154-159, 2011a.

Giri, C., Ochieng, E., Tieszen, L., Zhu, Z., Singh, A., Loveland, T., Masek, J., and Duke, N.: Global distribution of mangroves forests of the world using earth observation satellite data, in: Supplement to: Giri et al. (2011a), UNEP World Conservation Monitoring Centre, Cambridge, UK, available at: http://data. unep-wcmc.org/datasets/4 (last access: 1 June 2016), 2011 b.

Green, A., Smith, S. E., Lipsett-Moore, G., Groves, C., Peterson, N., Sheppard, S., Lokani, P., Hamilton, R., Almany, J., and Aitsi, J.: Designing a resilient network of marine protected areas for Kimbe Bay, Papua New Guinea, Oryx, 43, 488-498, 2009.

Guiry, M. D. and Guiry, G. M.: AlgaeBase, World-wide electronic publications, National University of Ireland, Galway, available at: http://www.algaebase.org/, last access: 1 August 2018.

Halpern, B. S., Walbridge, S., Selkoe, K. A., Kappel, C. V., Micheli, F., D’Agrosa, C., Bruno, J. F., Casey, K. S., Ebert, C., Fox, H. E., Fujita, R., Heinemann, D., Lenihan, H. S., Madin, E. M. P., Perry, M. T., Selig, E. R., Spalding, M., Steneck, R., and Watson, R.: A global map of human impact on marine ecosystems, Science, 319, 948-952, https://doi.org/10.1126/science.1149345, 2008.

Halpern, B. S., Frazier, M., Potapenko, J., Casey, K. S., Koenig, K., Longo, C., Lowndes, J. S., Rockwood, R. C., Selig, E. R., and Selkoe, K. A.: Spatial and temporal changes in cumulative human impacts on the world's ocean, Nat. Commun., 6, 7615, https://doi.org/10.1038/ncomms8615, 2015a.

Halpern, B. Frazier, M., Potapenko, J., Casey, K. S., Koenig, K., Longo, C., Lowndes, J. S., Rockwood, R. C., Selig, E. R., and Selkoe, K. A.: Cumulative human impacts: raw stressor data (2008 and 2013), https://doi.org/10.5063/F1S180FS 2015b.

Hamylton, S. M.: Spatial Analysis of Coastal Environments, Cambridge University Press, Cambridge, UK, 2017.

Heidorn, P. B.: Biodiversity informatics, Bulletin of the Association for Information Science and Technology, 37, 38-44, 2011.

Hoeksema, B. W.: Delineation of the Indo-Malayan centre of maximum marine biodiversity: the Coral Triangle, in: Biogeography, time, and place; Distributions, barriers, and islands, edited by: Renema, W., Springer, The Netherlands, 117-178, 2007.

Horton, T., Kroh, A., Bailly, N., Boury-Esnault, N., Brandão, S. N., Costello, M. J., Gofas, S., Hernandez, F., Mees, J., Paulay, G., Poore, G., Rosenberg, G., Stöhr, S., Decock, W., Dekeyzer, S., Vandepitte, L., Vanhoorne, B., Vranken, S., Adams, M. J., Adlard, R., Adriaens, P., Agatha, S., Ahn, K. J., Ahyong, S., Akkari, N., Alvarez, B., Anderson, G., Angel, M., Arango, C., Artois, T., Atkinson, S., Barber, A., Barbosa, J. P., Bartsch, I., Bellan-Santini, D., Berta, A., Bieler, R., Błażewicz, M., Bock, P., Böttger-Schnack, R., Bouchet, P., Boyko, C. B., Bray, R., Bruce, N. L., Cairns, S., Campinas Bezerra, T. N., Cárdenas, P., Carstens, E., Cedhagen, T., Chan, B. K., Chan, T. Y., Cheng, L., Churchill, M., Coleman, C. O., Collins, A. G., Cordeiro, R., Crandall, K. A., Cribb, T., Dahdouh-Guebas, F., Daly, M., Daneliya, M., Dauvin, J. C., Davie, P., De Grave, S., de Mazancourt, V., Decker, P., Defaye, D., d'Hondt, J. L., Dijkstra, H., Dohrmann, M., Dolan, J., Downey, R., Drapun, I., EisendleFlöckner, U., Eitel, M., Encarnação, S. C. d., Enghoff, H., Epler, J., Ewers-Saucedo, C., Faber, M., Feist, S., Finn, J., Fišer, C., Fonseca, G., Fordyce, E., Foster, W., Frank, J. H., Fransen, C., Furuya, H., Galea, H., Garcia-Alvarez, O., Gasca, R., GaviriaMelo, S., Gerken, S., Gheerardyn, H., Gibson, D., Gil, J., Gitten- 
berger, A., Glasby, C., Glover, A., Gordon, D., Grabowski, M., Gravili, C., Guerra-García, J. M., Guidetti, R., Guilini, K., Guiry, M. D., Hajdu, E., Hallermann, J., Hayward, B., Hendrycks, E., Herrera Bachiller, A., Ho, J. s., Høeg, J., Holovachov, O., Hooper, J., Hughes, L., Hummon, W., Hyzny, M., Iniesta, L. F. M., Iseto, T., Ivanenko, S., Iwataki, M., Jarms, G., Jaume, D., Jazdzewski, K., Kaminski, M., Karanovic, I., Kim, Y. H., King, R., Kirk, P. M., Kociolek, J. P., Kolb, J., Kotov, A., KrappSchickel, T., Kremenetskaia, A., Kristensen, R., Kullander, S., La Perna, R., Lambert, G., Lazarus, D., Le Coze, F., LeCroy, S., Leduc, D., Lefkowitz, E. J., Lemaitre, R., Lörz, A. N., Lowry, J., Macpherson, E., Madin, L., Mah, C., Mamos, T., Manconi, R., Mapstone, G., Marek, P. E., Marshall, B., Marshall, D. J., McInnes, S., Meidla, T., Meland, K., Merrin, K., Messing, C., Miljutin, D., Mills, C., Mokievsky, V., Molodtsova, T., Monniot, F., Mooi, R., Morandini, A. C., Moreira da Rocha, R., Moretzsohn, F., Mortelmans, J., Mortimer, J., Musco, L., Neubauer, T. A., Neuhaus, B., Ng, P., Nguyen, A. D., Nielsen, C., Nishikawa, T., Norenburg, J., O'Hara, T., Okahashi, H., Opresko, D., Osawa, M., Ota, Y., Patterson, D., Paxton, H., Perrier, V., Perrin, W., Petrescu, I., Picton, B., Pilger, J. F., Pisera, A., Polhemus, D., Pugh, P., Reimer, J. D., Reip, H., Reuscher, M., Rius, M., Rützler, K., Rzhavsky, A., Saiz-Salinas, J., Santos, S., Sartori, A. F., Satoh, A., Schatz, H., Schierwater, B., Schmidt-Rhaesa, A., Schneider, S., Schönberg, C., Schuchert, P., Senna, A. R., Serejo, C., Shamsi, S., Sharma, J., Shenkar, N., Short, M., Sicinski, J., Siegel, V., Sierwald, P., Simmons, E., Sinniger, F., Sivell, D., Sket, B., Smit, H., Smol, N., Souza-Filho, J. F., Spelda, J., Stampar, S. N., Sterrer, W., Stienen, E., Stoev, P., Strand, M., Suárez-Morales, E., Summers, M., Suttle, C., Swalla, B. J., Taiti, S., Tandberg, A. H., Tang, D., Tasker, M., Taylor, J., Tchesunov, A., ten Hove, H., ter Poorten, J. J., Thomas, J., Thuesen, E. V., Thurston, M., Thuy, B., Timi, J. T., Timm, T., Todaro, A., Turon, X., Tyler, S., Uetz, P., Utevsky, S., Vacelet, J., Vader, W., Väinölä, R., van der Meij, S. E., van Soest, R., Van Syoc, R., Venekey, V., Vonk, R., Vos, C., Walker-Smith, G., Walter, T. C., Watling, L., Wesener, T., Whipps, C., White, K., Williams, G., Wilson, R., Wyatt, N., Wylezich, C., Yasuhara, M., Zanol, J., and Zeidler, W.: World Register of Marine Species (WoRMS), WoRMS Editorial Board, available at: http://www.marinespecies.org/, last access: 1 June 2016.

IUCN: The IUCN Red List of Threatened Species, Version 2015.4, available at: https://www.iucnredlist.org/, last assess: 19 November 2015 .

IUCN and UNEP-WCMC: The World Database on Protected Areas (WDPA), UNEP - World Conservation Monitoring Centre, Cambridge, UK, available at: https://www.protectedplanet.net/, last assess: 1 August 2016.

Jetz, W., McPherson, J. M., and Guralnick, R. P.: Integrating biodiversity distribution knowledge: toward a global map of life, Trends Ecol. Evol., 27, 151-159, https://doi.org/10.1016/j.tree.2011.09.007, 2012.

Kaschner, K., Rius-Barile, J., Kesner-Reyes, K., Garilao, C., Kullander, S. O., Rees, T., and Froese, R.: AquaMaps; Predicted range maps for aquatic species, World Wide Web electronic publication, Version 08/2016, available at: http://www.aquamaps. org/, last assess: 1 August 2016.

Kot, C. Y., Fujioka, E., DiMatteo, A., Wallace, B., Hutchinson, B., Cleary, J., Halpin, P., and Mast, R.: The State of the World's Sea
Turtles Online Database, Data provided by the SWOT Team and hosted on OBIS-SEAMAP, Oceanic Society, IUCN Marine Turtle Specialist Group (MTSG), and Marine Geospatial Ecology Lab, Duke University, available at: http://seamap.env.duke.edu/ swot (last assess: 1 June 2016), 2015.

Marchante, H., Morais, M. C., Gamela, A., and Marchante, E.: Using a WebMapping platform to engage volunteers to collect data on invasive plants distribution, T. GIS, 21, 238-252, 2017.

Maynard, J. A., Mckagan, S., Raymundo, L., Johnson, S., Ahmadia, G. N., Johnston, L., Houk, P., Williams, G. J., Kendall, M., and Heron, S. F.: Assessing relative resilience potential of coral reefs to inform management, Biol. Conserv., 192, 109-119, 2015.

McLeod, E., Moffitt, R., Timmermann, A., Salm, R., Menviel, L., Palmer, M. J., Selig, E. R., Casey, K. S., and Bruno, J. F.: Warming Seas in the Coral Triangle; Coral Reef Vulnerability and Management Implications, Coast. Manage., 38, 518-539, https://doi.org/10.1080/08920753.2010.509466, 2010.

Michener, W. K.: Ecological data sharing, Ecol. Inform., 29, 33-44, 2015.

Michener, W. K., Brunt, J. W., Helly, J. J., Kirchner, T. B., and Stafford, S. G.: Nongeospatial metadata for the ecological sciences, Ecol. Appl., 7, 330-342, 1997.

MoF-MoMAF: Data of the Ecological representation gap analysis for conservation areas in Indonesia, Ministry of Forestry and Ministry of Marine Affairs and Fisheries, Jakarta, Indonesia, 2010.

MoMAF: The database of Marine Protected Areas in Indonesia, Ministry of Marine Affairs and Fisheries, Jakarta, Indonesia, 2016.

Morets, D.: Internet GIS, in: Encyclopedia of GIS, edited by: Shekhar, S., Xiong, H., and Zhou, X., Springer International, Cham, Switzerland, 1074-1081, 2017.

Neumann, A.: Web Mapping and Web Cartography; Encyclopaedia of GIS, Springer, Boston, MA, 1261-1269, 2008.

OBIS: Data from the Ocean Biogeographic Information System, Intergovernmental Oceanographic Commission of UNESCO, available at: http://www.iobis.org/, last access: 22 January 2015.

Polidoro, B. A., Carpenter, K. E., Collins, L., Duke, N. C., Ellison, A. M., Ellison, J. C., Farnsworth, E. J., Fernando, E. S., Kathiresan, K., Koedam, N. E., Livingstone, S. R., Miyagi, T., Moore, G. E., Vien, N. N., Ong, J. E., Primavera, J. H., Salmo, S. G., Sanciangco, J. C., Sukardjo, S., Wang, Y. M., and Yong, J. W. H.: The loss of species: Mangrove extinction risk and geographic areas of global concern, Plos One, 5, e10095, https://doi.org/10.1371/journal.pone.0010095, 2010.

Parr, C. S. and Thessen, A. E.: Biodiversity Informatics, in: Ecological Informatics; Data Management and Knowledge Discovery, edited by: Recknagel, F. and Michener, W. K., Springer International Publishing, Cham, Switzerland, 375-399, 2018.

Pauly D. and Zeller D. (Eds.): Sea Around Us Concepts, Design and Data, available at: http://www.seaaroundus.org/ (last access: 1 April 2018), 2015.

Peterson, M. P.: International perspectives on maps and the Internet, Springer, Berlin Heidelberg, 2018.

Reichman, O. J., Jones, M. B., and Schildhauer, M. P.: Challenges and opportunities of open data in ecology, Science, 331, 703705, 2011

Saeedi, H., Dennis, T. E., and Costello, M. J.: Bimodal latitudinal species richness and high endemicity of razor clams (Mollusca), 
J. Biogeogr., 44, 592-604, https://doi.org/10.1111/jbi.12903, 2016.

Sui, D.: Opportunities and Impediments for Open GIS, T. GIS, 18, 1-24, https://doi.org/10.1111/tgis.12075, 2014

Teacher, A. G., Griffiths, D. J., Hodgson, D. J., and Inger, R.: Smartphones in ecology and evolution; A guide for the app-rehensive, Ecol. Evol., 3, 5268-5278, 2013.

UNEP-WCMC: The Checklist of CITES Species Website, CITES Secretariat, Geneva, Switzerland, Compiled by UNEP-WCMC, Cambridge, UK, available at: http://checklist.cites.org (last access: 1 February 2016), 2015.

UNEP-WCMC and Short, F. T.: Global distribution of seagrasses (version 3.0), 3rd update to the data layer used in Green and Short (2003), UNEP World Conservation Monitoring Centre, Cambridge, UK, available at: http://data.unep-wcmc.org/datasets/7 (last access: 1 June 2016), 2005.

UNEP-WCMC, WorldFish Centre, WRI, and TNC: Global distribution of coral reefs, compiled from multiple sources including the Millennium Coral Reef Mapping Project, Version 1.3, updated by UNEP-WCMC, includes contributions from IMaRS USF and IRD (2005), IMaRS-USF (2005) and Spalding et al. (2001), UNEP World Conservation Monitoring Centre, Cambridge, UK, available at: http://data.unep-wcmc.org/datasets/1 (last access: 1 June 2016), 2010.

Veron, J., Devantier, L. M., Turak, E., Green, A. L., Kininmonth, S., Stafford-Smith, M., and Peterson, N.: Delineating the Coral Triangle, Galaxea, Journal of Coral Reef Studies, 11, 91-100, 2009.
VLIZ: Maritime Boundaries Geodatabase, Version 8, available at: http://www.marineregions.org/ (last access: 22 March 2016), 2014.

Van Hooidonk, R., Maynard, J., Tamelander, J., Gove, J., Ahmadia, G., Raymundo, L., Williams, G., Heron, S. F., and Planes, S.: Local-scale projections of coral reef futures and implications of the Paris Agreement, Sci. Rep., 6, 39666, https://doi.org/10.1038/srep39666, 2016.

Wright, D., Pendleton, M., Boulware, J., Walbridge, S., Gerlt, B., Eslinger, D., Sampson, D., and Huntley, E.: ArcGIS Benthic Terrain Modeler (BTM), V. 3.0, Environmental Systems Research Institute (ESRI), NOAA Coastal Services Centre, Massachusetts Office of Coastal Zone Management, Redlands, CA, 2012.

Wright, D. J. (Ed.): Ocean Solutions, Earth Solutions, 2nd edn., Esri Press, Redlands, CA, 2016.

Wright, D. J, Dwyer, N., and Cummins, V. (Eds.): Coastal Informatics: Web Atlas Design and Implementation, IGI-Global, Hershey, New York, 2011.

Walton, A., White, A. T., Tighe, S., Alino, P. M., Laroya, L., Dermawan, A., Kasasiah, A., Hamid, S. A., VaveKaramui, A., Genia, V., Martins, L. D., and Green, A. L.: Establishing a functional region-wide Coral Triangle marine protected area system, Coast. Manage., 42, 107-127, https://doi.org/10.1080/08920753.2014.877765, 2014. 